\title{
Filsafat Islam Antara Agama Dan Logika
}

\author{
Wendy afriansyah ${ }^{1}$, Ahmad $^{2}$, \\ Dosen Pembimbing : Ibnu Hajar Sainuddin ${ }^{3}$
}

\begin{abstract}
Sekolah Tinggi Agama Islam (STAI) Darut Dakwah Wal-Irsyad (DDI) Kota Makassar,Indonesia Email: afriansyahabdullah28@gmail.com

Sekolah Tinggi Agama Islam (STAI) Darut Dakwah Wal-Irsyad (DDI) Kota Makassar,Indonesia Email: Hajarudinahmad833@gmail.com

Sekolah Tinggi Agama Islam (STAI) Darut Dakwah Wal-Irsyad (DDI) Kota Makassar,Indonesia Email: Ibnuhajar@staiddimakassar.ac.id
\end{abstract}

\begin{abstract}
ABSTRAK
Allah SWT menjadikan Agama Islam adalah sebagai fitrah bagi manusia sekaligus menunjukan kepada manusia agar dapat mencapai kebahagiaan dunia dan akhirat, dan akal logika adalah sebagai alat dalam memahami setiap perkara pokok permasalahan dalam menjalani ibadah,muammalah,muasyaroh dan akhlaq dalam kehidupan sehari hari agar dapat menjalankan ibadah dengan mudah dan tidak mempersuit dalam menjlankan ritual agama berdasarkan kadar keimanan dan kemampuan seseorang, akan tetapi akal logika tidak dapat di jadikan sebagai alat petunjuk dalam menjalankan ritual agama dalam kehidupan sebab akal logika bisa di kendalikan oleh hawa nafsu dalam menjalankan misi ibadah.
\end{abstract}

\section{Kata Kunci : Filsaf Islam Antara Logika Dan Agama}

\section{A. PENDAHULUAN}

Logika adalah suatu cabang filsafat yang membahas tentang aturan-aturan, asassasa, hukum-hukum dan metode atau prosedur dalam mencapai pengetahuan secara rasional dan benar, juga merupakan suatu cara untuk mendapatkan suatu pengetahuan dengan menggunakan akal pikiran, kata dan bahasa yang dilakukan secara sistematis. Logika dapat disistematisasikan menjadi beberapa golongan hal tersebut tergantung dari perspektif mana kita melihatnya dilihat dari kualitasnya logika dapat dibedakan menjadi dua yakni logika naturalis ( logika alamiah) dan logika artifisialis (logika ilmiah). Penalaran merupakan suatu proses berpikir dalam menarik sesuatu kesimpulan yang berupa pengetahuan. Manusia pada hakikatnya merupakan makhluk yang berpikir, merasa, bersikap, dan bertindak. Sikap dan tindakannya yang bersumber pada 
pengetahuan yang didapatkan melalui kegiatan merasa atau berpikir. Penalaran menghasilkan pengetahuan yang dikaitkan dengan kegiatan berpikir. Penalaran merupakan suatu proses berpikir dalam menarik sesuatu kesimpulan yang berupa pengetahuan. Jadi penalaran merupakan salah satu atau proses dalam berpikir yang menggabungkan dua pemikiran atau lebih untuk menarik sebuah kesimpulan untuk mendapatkan pengetahuan baru.

\section{B. PEMBAHASAN}

\section{Agama Dan Logika}

Agama merupakan fenomena universal umat manusia. Meski tidak semua manusia kemudian beragama, namun pada Kenyataannya, mereka punya keyakinan masing-masing tentang yang transenden. Di sisi lain, ketika manusia beragama, yang sering terjadi adalah pemutlakan terhadap kebenaran agama masing-masing. Pemutlakan ini pada akhirnya bisa menutup pintu dialog. Karena itu, mendiskusikan kembali kebenaran agama menjadi penting dilakukan. Tulisan ini hendak menginventarisir berbagai pandangan para filsuf agama tentang makna kebenaran agama. Tokoh utama yang dijadikan dasar pengkajian adalah John Hiks dan W.C Smith berdasarkan teori kebenaran agama yang ditulis oleh Hendrik M. Vroom yang berjudul "Religions and The Truth, Philosophical Reflection and Perspectives". Tentang kebenaran agama, John Hiks menyimpulkan bahwa kebenaran bisa diperoleh dari agama apapun, karenanya jalan keselamatan dimiliki oleh semua agama. Sehingga pada akhirnya, semua manusia sebenarnya sedang menyembah pada Tuhan yang sama (divine One). Sementara itu W.C. Smith menyimpulkan bahwa dalam beragama yang paling inti adalah to love god (mencintai Tuhan). Kebenaran tunggal adalah milik Tuhan, sementara kebenaran pada tataran manusia adalah kebenaran dengan "b" kecil yang bersifat nisbi ${ }^{1}$.

Agama dan filsafat sekilas merupakan dua kata yang berdiri sendiri dan antara keduanya tidak ada hubungan yang mengikat dan tidak ada korelasi. Bahkan menurut pandangan sebagian besar orang kedua kata tersebut cenderung berseberangan dan bertolak belakang. Memang benar bayangannya hanya pada pola dasar dan landasan yang tempat kedua kata tersebut dibentuk. Agama didasarkan pada petunjuk dan otoritas wahyu yang bersifat absolut, sedangkan filsafat menekankan pembahasan dan

\footnotetext{
${ }^{1}$ Nur, M. (2011). Tuhan, Agama, Dan Kebenaran (Membaca Ulang Logika Kebenaran Agama Dalam Kerangka Pemikiran Filsafat). Al-Adyan: Jurnal Studi Lintas Agama, 6(1), 85-98.
} 
didasarkan pada pemikiran, penalaran dan akal yang universal. Tetapi secara lebih jauh keduanya mempunyai persamaan-persamaan dan cenderung saling berhubungan dan saling membutuhkan. Agama dan filsafat sama-sama berkaitan dengan metafisik, mempunyai objek pembahasannya adalah sama-sama manusia, yang menjadi subjek adalah tentang ketuhanan, sama sebagai pondasi tempat berdirinya kebenaran dan sumber dari ilmu pengetahuan. Banyak para agamawan dan filosof yang mempertentangkan kedudukan filsafat dan agama dalam pencaharian kebenaran, tetapi itu adalah ijtihad dan pemikiran mareka, yang jelas fungsi dan kedudukan agama dan filsafat tersebut tidak akan luntur dan bergeser hanya karena perbedaan pendapat orang yang melihatnya, justeru perbedaan-perbedaan tersebut akan semakin memantapkan fungsi dan kedudukannya tersebut ${ }^{2}$.

Sejarah perkembangan peradaban Islam dibagi menjadi tiga bagian, yaitu: periode klasik (650 -1250 M), periode pertengahan (1250-1800 M) dan periode modern (1800-sekarang). Pada masa klasik diskursus keilmuan Islam mencapai tingkat sehingga kemudian dapat disumbangkan pada berkembangnya ilmu pengetahuan di masa-masa sesudahnya. Kompleksitas ilmu-ilmu yang berkembang dalam peradapan Islam; bahwa ilmu-ilmu agama hanya salah satu bagian dari berbagai cabang ilmu secara keseluruhan. Kemajuan peradaban Islam berkaitan dengan kemajuan seluruh aspek atau bidang-bidang keilmuan. Dengan adanya pembagian ilmu dari berbagai ilmuwan Muslim, tak jarang terjadi disharmoni antara berbagai bidang ilmu keislaman. Untuk mengatasi disharmoni ini berbagai pemikir dan cendikia Muslim memunculkan klasifikasi ilmu-ilmu lengkap dengan hierarkinya. Dalam Islam sebenarnya tidak dikenal pemisahan esensial antara ilmu agama dengan ilmu umum. Perpustakaan dalam mengelola berbagai jenis bahan pustaka disusun juga menurut tata urutan tertentu sebelum sampai ke tangan pengguna. Pedoman klasifikasi Islam pertama kali diterbitkan oleh perpustakaan Nasional adalah-Klasifikasi Bahan Pustaka tentang Indonesia Menurut DDC menggunakan notasi 2X0. Dalam penyusunan pedoman klasifikasi Islam, ilmu keislaman dibagi dalam kelompok besar meliputi: Islam (Umum), Tafsir, Hadis, Aqaid dan ilmu kalam, Fiqih, Akhlak dan Tasawuf, Sosial dan Budaya Islam, Filsafat dan perkembangan Islam, Aliran dan Sekte dalam Islam, serta sejarah Islam $^{3}$.

Di era modern agama memiliki peran penting dalam masyarakat sebagai pedoman serta memposisikan diri untuk berdampingan dengan zaman yang terus maju

\footnotetext{
${ }^{2}$ Saifuddin, S. (2018). KAJIAN AGAMA DAN FILSAFAT TENTANG KEBENARAN. Jurnal IImiah Islam Futura, 7(2), 73-83.

${ }^{3}$ Tadjuddin, M. S., Sani, M. A. M., \& Yeyeng, A. T. (2017). Dunia Islam dalam Lintasan Sejarah dan Realitasnya di Era Kontemporer.
} 
dan berkembang sehingga tidak menyimpang, Di sisi lain, perkembangan demokrasi serta kemajuan tekhnologi informasi, tentunya masyarakat dari berbagai lapisan dengan mudah mengetahui hal hal yang berkaitan dengan agama. Informasi keagamaan dapat dengan mudah di kemas baik dalam bentuk buku, video atau di berbagai platform media sosial. Di sisi lain, Moderasi beragama juga mampu memoengaruhi mental. Dengan demikian, bahwa sesungguhnya Islam telah siap menghadapi dan mengambil peran bagi umat Islam di modern apakah sebagai penonton atau sebagai pemeran aktif dan pemotor kekuatan dalam kemajuan Islam ${ }^{4}$.

\section{Peranan Logika}

Logika secara etimologis berasal dari bahasa Yunani dari kata "logike" yang berhubungan dengan kata "logos" yang berarti ucapan, atau pikiran yang diucapkan secara lengkap. Logika sebagai suatu studi secara sederhana dapat kita batasi sebagai suatu kajian tentang bagaimana seseorang mampu untuk berpikir dengan lurus.

Logika adalah bidang pengetahuan yang merupakan bagian dari filsafat yang mempelajari segenap asas, aturan, dan tatacara mengenai penalaran yang benar. Dengan kata lain) "logic is the study of methods and principles used distinguish good (correct) from bad (incorrect) reasoning".

Logika dalam istilah lain digunakan sebagai gantinya adalah "mantiq", kata Arab yang diambil dari kata kerja "nathaqa" yang berarati berkata atau berucap. Dalam bahasa sehari-hari kita sering mendengar ungkapan serupa: 'alasannya tidak logis', 'argumentasi logis', 'kabar itu tidak logis'. Yang dimaksud dengan logis adalah masuk akal, dan tidak logis adalah sebaliknya5.

Oleh karena itu, meskipun agama dan logika adalah dua unsur yang berbeda, akan tetapi saling memberi pengaruh yang sangat besar untuk memahami suatu perkara, baik itu hal hal yang berhubungan dengan agama maupun hal hal yang berkaitan dalam urusan duniawi sekalipun.

\section{PENUTUP}

Demikian yang dapat kami paparkan mengenai materi yang menjadi pokok dalam Makalah ini, tentunya masih banyak kekurangan dan kelemahannya karena terbatasnya pengetahuan dan kurangnya rujukan atau referensi yang ada hubunganya dengan judul makalah ini.

\footnotetext{
${ }^{4}$ Sainuddin, I. H. Moderasi Beragama dan Radikalisme di Era Modern.

${ }^{5}$ Logicand Language of Education
} 


\section{DAFTAR PUSTAKA}

1. Nur, M. (2011). Tuhan, Agama, Dan Kebenaran (Membaca Ulang Logika Kebenaran Agama Dalam Kerangka Pemikiran Filsafat). Al-Adyan: Jurnal Studi Lintas Agama, 6(1), 85-98.

2. Saifuddin, S. (2018). KAJIAN AGAMA DAN FILSAFAT TENTANG KEBENARAN. Jurnal IImiah Islam Futura, 7(2), 73-83.

3. Tadjuddin, M. S., Sani, M. A. M., \& Yeyeng, A. T. (2017). Dunia Islam dalam Lintasan Sejarah dan Realitasnya di Era Kontemporer.

4. Sainuddin, I. H. Moderasi Beragama dan Radikalisme di Era Modern.

5. Logicand Language of Education 